\title{
Examining Effects of the COVID-19 National Lockdown on Ambient Air Quality Across Urban India
}

\author{
Chimurkar Navinya ${ }^{1}$, Girish Patidar ${ }^{1}$, Harish C. Phuleria ${ }^{1,2 *}$ \\ ${ }^{1}$ Interdisciplinary Program in Climate Studies, Indian Institute of Technology Bombay, Mumbai - 400076, Maharashtra, \\ India \\ ${ }^{2}$ Environmental Science and Engineering Department, Indian Institute of Technology Bombay, Mumbai - 400076, \\ Maharashtra, India
}

\begin{abstract}
Lockdown seems the most effective way to prevent the spread of Coronavirus disease (COVID-19) as no vaccine is currently available in the market to cure it. Thus, India has enforced nation-wide lockdown from $25^{\text {th }}$ March to lower the spread of this contagious virus and associated illness. This study aims to quantify the changes in pollution levels as well as meteorology during the 6-weeks COVID-19 lockdown over 17 cities of India for 5 major criteria pollutants using publicly available air quality data. Hourly averaged data is accessed from the air quality monitoring stations during the lockdown and immediate pre-lockdown periods and also corresponding data from the previous year (2019). During the lockdown, $\mathrm{PM}_{2.5}$, $\mathrm{PM}_{10}, \mathrm{NO}_{2}$, and $\mathrm{CO}$ reduced significantly with relatively small changes in meteorological conditions compared to the prelockdown period. The highest decline is observed over Ahmedabad (68\%), Delhi (71\%), Bangalore (87\%), and Nagpur (63\%) for $\mathrm{PM}_{2.5}, \mathrm{PM}_{10}, \mathrm{NO}_{2}$, and $\mathrm{CO}$, respectively. The Northern region shows the highest decline for all the pollutants with most days below NAAQS during lockdown-86\%, 68\%, and $100 \%$ compared to $18 \%$, $0 \%$, and $38 \%$ in 2019 for $\mathrm{PM}_{2.5}$, $\mathrm{PM}_{10}$, and $\mathrm{NO}_{2}$, respectively. The smaller cities Dewas and Jorapokhar show lesser improvement with only 3\% and $16 \%$ improvement in days under NAAQS for $\mathrm{PM}_{2.5}$. $\mathrm{SO}_{2}$ is the least affected pollutant with little improvement. The major decline is observed during 7-10 am and 7-10 pm hours of the day for $\mathrm{PM}_{2.5}, \mathrm{PM}_{10}, \mathrm{NO}_{2}$, and $\mathrm{CO}$ with more than $40 \%$ reduction. The meteorological changes are very small and heterogeneous over India showing a similar extent of changes compared to the previous year but the pollution levels have reduced significantly. Thus, the sharp decline in pollutant concentration during the $\sim 6$ weeks period national lockdown can be attributed to the reduced economic and transport activities.
\end{abstract}

Keywords: COVID-19; Urban air pollution; India; Lockdown; $\mathrm{PM}_{2.5}$.

\section{INTRODUCTION}

The world is suffering from the Coronavirus disease (COVID-19) with $\sim 5$ million cases and $\sim 330,000$ deaths altogether in 216 countries as of $22^{\text {nd }}$ May, 2020 (WHO, 2020). This novel Coronavirus, which is initially detected in the Wuhan, China, causes mild to moderate respiratory illness and due to its rapid spread, World Health Organisation declared it as a pandemic on $30^{\text {th }} \mathrm{Jan}, 2020$ (Lu et al., 2020). Since then, it has affected almost every country on the planet (WHO, 2020). This virus can be spread due to direct contact with an infected person or touching any virus carrying surface but the major issue with this virus is its non-distinguishable symptoms which are flu, fever, sore

\footnotetext{
* Corresponding author.

Tel.: +9122 25765851

E-mail address: phuleria@iitb.ac.in
}

throat, and dry cough (Huang et al., 2020). The virus has gained global attention due to its highly contagious nature and the unavailability of standard vaccines (Lu, 2020). Thus, this pandemic has forced most countries to declare lockdown as a preventive measure to avoid the spread of the virus. Hence, the major anthropogenic sources of emissions in urban areas, the transport sector, in particular, have significantly reduced during this lockdown (MHA, 2020a).

India is also affected by this virus with $\sim 125,000$ active cases and $\sim 3,700$ deaths as of $22^{\text {nd }}$ May, 2020 (MoHFW India, 2020) but the per capita cases are relatively lesser than other developed countries. The Indian government has taken an early call to eliminate the spread of the virus by declaring lockdown from $25^{\text {th }}$ Mar to $14^{\text {th }}$ Apr, 2020, which was extended until $3^{\text {rd }}$ May, 2020 and further until $17^{\text {th }}$ May, 2020 with some provision of movement of the essential services and goods (MHA, 2020b). All the education institutes, private firms, inter-state transport via bus, train and aeroplane are not functioning during the lockdown. Hence, there is a possibility of a reduction in air pollution levels due 
to reduced anthropogenic activities like transports, which contributes significantly to the air emissions (Ramachandra and Shwetmala, 2009; Pandey and Venkataraman, 2014). Considering the consequence of reduced or stopped anthropogenic activities, the lockdown is expected to change the air pollution levels over India similar to what has been reported for $\mathrm{NO}_{2}$ over Wuhan, China in the early stage of lockdown (NASA, 2020).

A few recent studies have examined the decline of air pollution levels during the early COVID-19 lockdown at various locations around the world with majority of the studies conducted over China as it was the first nation to declare the lockdown. Xu et al. (2020) reported 30\%, 40\%, $33 \%, 61 \%$, and $28 \%$ reduction in $\mathrm{PM}_{2.5}, \mathrm{PM}_{10}, \mathrm{SO}_{2}, \mathrm{NO}_{2}$, and $\mathrm{CO}$, respectively when averaged over three cities of Central China during February 2020 compared to 20172019. Eastern China showed lower decline during lockdown for $\mathrm{CO}(\sim 20 \%)$ and $\mathrm{NO}_{2}(\sim 30 \%)$ compared to previous year, mainly related to reduced usage of coal and oil (Filonchyk et al., 2020), whereas Northern China reported 5.9\%, 13.6\%, $6.8 \%, 24.7 \%$, and $4.6 \%$ reduction for $\mathrm{PM}_{2.5}, \mathrm{PM}_{10}, \mathrm{SO}_{2}$, $\mathrm{NO}_{2}$, and $\mathrm{CO}$ compared to the pre-lockdown period (Bao and Zhang, 2020). Another study investigating 336 urban areas cross China reported 14\%, 15\%, 12\%, 16\%, and 12\% reduction in $\mathrm{PM}_{2.5}, \mathrm{PM}_{10}, \mathrm{SO}_{2}, \mathrm{NO}_{2}$, and $\mathrm{CO}$, respectively during lockdown over China compared to 2019 (Chen et al., 2020). Whereas, satellite data from the Ozone Monitoring Instrument (OMI) shows a $48 \%$ drop in tropospheric $\mathrm{NO}_{2}$ column-averaged over 20 days of the lockdown in China (Liu et al., 2020). Cadotte (2020) has also observed a decline in $\mathrm{PM}_{2.5}$ and $\mathrm{NO}_{2}$ by 14 and $34 \%$ over China during January 2020 compared to a previous year respectively. A modeled study using the Community Multi-Scale Air Quality (CMAQ) shows a $20 \%$ decline in $\mathrm{PM}_{2.5}$ over Wuhan, China compared to an unchanged emission scenario if 80 and $20 \%$ transport and industrial emissions reduced respectively due to lockdown (Wang et al., 2020). The overall 25\% improvement can be seen in the air quality index over China compared to the same period of the previous year (He et al., 2020). Studies conducted over Europe found that after two weeks of lockdown (starting from 14 Mar, 2020) black carbon and $\mathrm{NO}_{2}$ reduced by 45 and $51 \%$ over Barcelona, Spain compared to pre lockdown period respectively (Tobías et al., 2020). Kerimray et al. (2020) reported $35 \%$ and $49 \%$ reduction in $\mathrm{NO}_{2}$ and $\mathrm{CO}$, respectively but a $7 \%$ increase in $\mathrm{SO}_{2}$ compared to pre-lockdown period over Almaty, Kazakhstan. In Rio de Janeiro, Brazil, $40 \%$ reduction in CO, which is attributed to reduce light duty vehicles emission, is reported during partial lockdown compared to previous year (Dantas et al., 2020). The World's Air Pollution: Real-time Air Quality Index (WAQI project) shows a monthly mean decline of $\mathrm{PM}_{2.5}$ for February are $57 \%, 53 \%, 47 \%, 45 \%$, and $45 \%$ over Vienna, Paris, Amsterdam, London, and Dublin respectively (Shrestha et al., 2020). Similarly, a few of the studies examining early lockdown impact over Indian cities using ground monitoring data, show 50\% decline in PM over India with Delhi showing highest decline even while meteorology was unfavourable for such high reduction (Mahato et al., 2020; Sharma et al., 2020). Satellite data also shows 50\% improvement in the air quality over India (Gautam, 2020).

A few studies have also examined the likely impact of the decline in air pollution during the lockdown on morbidity and mortality. More number of deaths are avoided by preventing ambient air pollution than the deaths due to COVID-19 (Isaifan, 2020). A satellite data used for the global inhabited area shows $10.7 \%$ decline in $\mathrm{NO}_{2}$ as China, and India shows the highest reduction $20 \%$, and $25 \%$ related to 2019 with total $427(235,619)$ and $52(29,76)$ deaths can be avoided during 2 weeks of lockdown (Venter et al., 2020). They also suggest 0.78 million deaths and 1.6 million pediatric asthma cases can be avoided globally, assuming the same pollution level maintained over 2020. $\mathrm{NO}_{2}(40 \%)$ and PM (10\%) reduction over Europe due to $37 \%$ fall in coal consumption from power plants, resulted in 11,000 (7,000, $21,000)$ avoided deaths from air pollution respectively (Myllyvirta, 2020). In a hypothetical scenario, an $\mathrm{NO}_{2}$ decrease of $30 \%$ could result in a $6 \%$ reduction in mortality equivalent of $\sim 100,000$ lives saved in China (Dutheil et al., 2020).

While more and more countries have implemented lockdowns to counter the COVID-19 spread, the data is being examined across the globe and the decline in pollution levels is not homogeneous. This could be due to natural change in meteorological factors simultaneously during the lockdowns (Schiermeier, 2020) as well due to likely increase in some other sources such as residential activities and household consumption (McNeill, 2020). The anthropogenic activities may also affect the meteorological parameters but the time scale required is very large compared to the given lockdown periods. The changes in the temperature in 50 years due to the increase in human activities combined with natural internal variability is $\sim 0.25 \mathrm{~K}$ (Tett et al., 1999). The changes in wind speed are mainly depending on the large scale circulation and land use land cover change (Wu et al., 2018). Whereas, water vapor content may increase due to human activities in an indirect way as it participates in a climate feedback system (Boucher et al., 2004). However, the lockdown period may have been too short to bring significant changes in any of the meteorological parameters. But such large changes in air pollution may not be induced by small meteorological changes alone (Schiermeier, 2020). Sharma et al. (2020) have investigated response of meteorological parameters over this unprecedented national/regional lockdown on the changes in air pollution levels in Delhi, India. But the changes in air quality in other Indian cities explicitly due to reduced anthropogenic activities have not been examined.

A past study showed that the transport sector in India including aviation and trains can emit $\mathrm{PMs}, \mathrm{CO}$, and $\mathrm{SO}_{2}$ up to $153.1,5692.1$ and $709.1 \mathrm{Gg}_{\text {year }}{ }^{-1}$ (Ramachandra and Shwetmala, 2009). Thus, four weeks of lockdown might have reduced $\sim 7.6 \%$ of total emissions from the transport sector. In earlier studies, it can be found that wind speed has a huge impact on the pollution level as it decides the rate of dispersion (Chaloulakou et al., 2003). Whereas, the relationship between pollutants and temperature is complex due to a two-way interaction, as temperature may cause atmospheric inversions which can increase ground level pollutant concentrations, 
while optical properties of pollutants, specifically fine particulate matter, can affect the temperature (Wallace and Kanaroglou, 2009).

The changes in pollution levels before and during lockdown may be driven by meteorological changes as well as due to a drastic reduction in anthropogenic activities during the lockdown. Government of India enforced the first national lockdown on $25^{\text {th }}$ Mar, 2020 for three weeks, which was extended for another three weeks ( $14^{\text {th }} \mathrm{Apr}-3^{\text {rd }}$ May). However, a detailed study on impact of the extended 6-week lockdown on air quality across Indian cities using ground in-situ data comparing it with previous concentrations is missing. Moreover, the changes in meteorology during the lockdowns haven't been examined for any region, either. Thus, this study aims to evaluate the changes in air pollutant levels and meteorology during the lockdown period over India and assess the impact of the lockdown on air quality over urban areas across the country.

\section{METHODOLOGY}

The criteria air pollutants are being monitored by the central pollution control board (CPCB) over 573 monitoring stations in 240 Indian cities with the finest temporal resolution of 15 minutes (CPCB, 2011, 2020; ENVIS, 2020) The standard measurement methods are used to quantify the concentrations. $\mathrm{PM}_{\mathrm{x}}, \mathrm{SO}_{2}, \mathrm{NO}_{2}$, and $\mathrm{CO}$ are measured using the tapered element oscillating microbalance (TEOM), Improved West and Gaeke Method, Jacob \& Hochheiser modified method, and Non-dispersive Infrared (NDIR) Spectroscopy, respectively (CPCB, 2011). The hourly concentration of $\mathrm{PM}_{2.5}, \mathrm{PM}_{10}, \mathrm{SO}_{2}, \mathrm{NO}_{2}$, and $\mathrm{CO}$ over 17 cities, one station in each city, were considered for analysis as shown in Fig. 1 (details provided in Supplementary report, Table S1). Four-time periods viz. 1 Feb-24 Mar, 2019 (termed hereafter as P19), 25 Mar-3 May, 2019 (L19), 1 Feb24 Mar, 2020 (P20) and 25 Mar-3 May, 2020 (L20) were chosen to examine the variation of air pollutant concentration. The time period of interest, L20 is the $\sim 6$ weeks national lockdown period due to the COVID-19 outbreak in India, whereas, P20, an $\sim 8$ weeks period immediately before the lockdown was used to compare and contrast the earlier pollution levels with an uninterrupted lifestyle. A longer pre-lockdown period, P20, was taken to accommodate the earlier partial lockdowns in some of the states prior to nationwide lockdown, and thus completely separating the lockdown period (i.e., L20) from prior period with uninterrupted lifestyle and economic activities. Since the pre-lockdown period includes February (the last month of winter) with lower temperatures, particularly in Northern India compared to the lockdown period (Spring season), last year's concentrations during the analogous periods, P19 and L19, are also considered for comparing with the 2020 air pollution levels.

Three meteorological parameters, wind speed (WS), temperature $(\mathrm{T})$, and relative humidity $(\mathrm{RH})$ from the weather stations from the same CPCB stations are used to verify any abnormal changes during the national lockdown

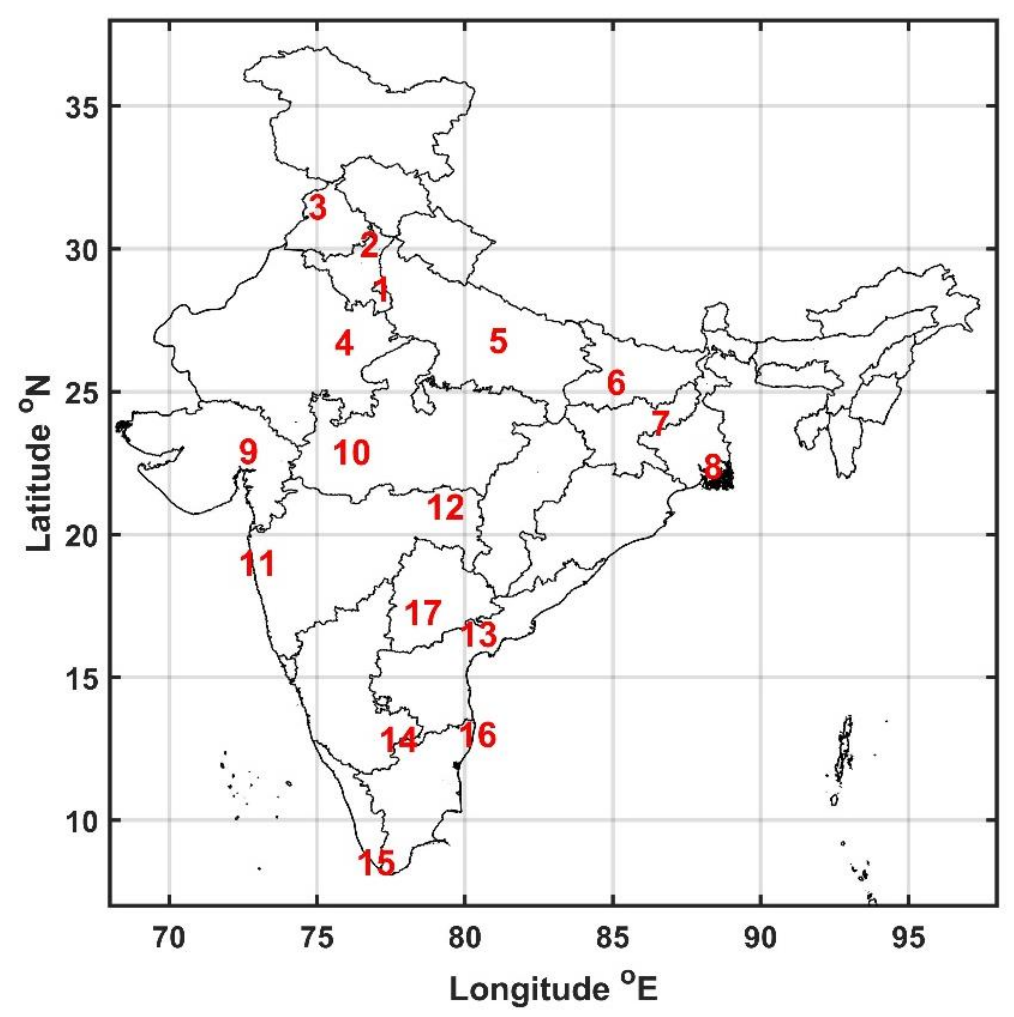

Fig. 1. The location of CPCB stations used in this study. 1) Delhi, 2) Ambala, 3) Amritsar, 4) Jaipur, 5) Lucknow, 6) Patna 7) Jorapokhar, 8) Kolkata, 9) Ahmedabad, 10) Dewas, 11) Mumbai 12) Nagpur, 13) Amaravati, 14) Bangalore, 15) Trivandrum, 16) Chennai and 17) Hyderabad. (One station in each city). 
and account for the changes in pollutant concentrations due to reduced anthropogenic activities against meteorological influences. The data is examined for any obscure values and removed, if found much beyond the explainable range before the analysis. The inter-comparison is conducted between the four time periods (P19, L19, P20, and L20) for all the five criteria pollutants as well as three meteorological parameters. Mean daily and diurnal variations are examined in meteorology along with the comparison among stations using the $\mathrm{CPCB}$ data as provided from the publicly accessible portal. To understand the relative impact of meteorology and activity reduction during the lockdown, the normalized percent change in the meteorological and air pollution between the lockdown (L20) and analogous period from previous year (L19) is examined (along with other paired comparisons, i.e., L20 vs. L19 and L19 vs. P19).

Statistical analysis includes the pairwise comparison based on Student t-test with Bonferroni correction. For each of the pollutant and meteorological parameters for every stations, four comparisons are made (L20 vs. P20, L20 vs. L19, L19 vs. P19 and P19 vs. P20) thus a Bonferroni corrected $\mathrm{p}$ value of 0.0125 , is used for statistical significance (Cleophas et al., 2011). Additionally, a $2 \times 17$ factorial Analysis of Variance (ANOVA) analysis is used to examine the data altogether from all stations for examining the relative changes for P19/P20 vs. L19/L20 (Lani, 2010). To further separate out the changes in air quality due to concurrent changes in meteorology and activities reduction due to national lockdown is examined by using ANOVA with a difference-in-difference (DiD) method (Ghei and Sane, 2018; He et al., 2020) between 2019 and 2020. Lastly, the air quality impact during and before lockdown is also examined by comparing the daily exceedance of National Ambient Air Quality Standards (NAAQS) in India. All data analysis is done using MS Excel 2013 and MATLAB R2017b.

\section{RESULTS AND DISCUSSION}

\section{Meteorology}

The daily variation in all three meteorological parameters averaged over all 17 cities show similar variation during the four time periods (during and pre-lockdown for year 2019 and 2020) with overlapping standard deviations (Fig. 2). The wind speed and temperature show a slightly increasing trend with the constant decline in relative humidity throughout the study period over India which might be attributed to seasonal change as season shifts from pre-monsoon to monsoon with expected onset on first week of June 2020 (Kothawale et al., 2010; IMD, 2020). The difference between 2019 and 2020 doesn't show any abnormal fluctuations before and after the lockdown. When examined for individual cities, the average wind speed over the pre-lockdown and lockdown periods compared to 2019 are similar for all the cities except Ahmedabad (Fig. S1). However, the temperature
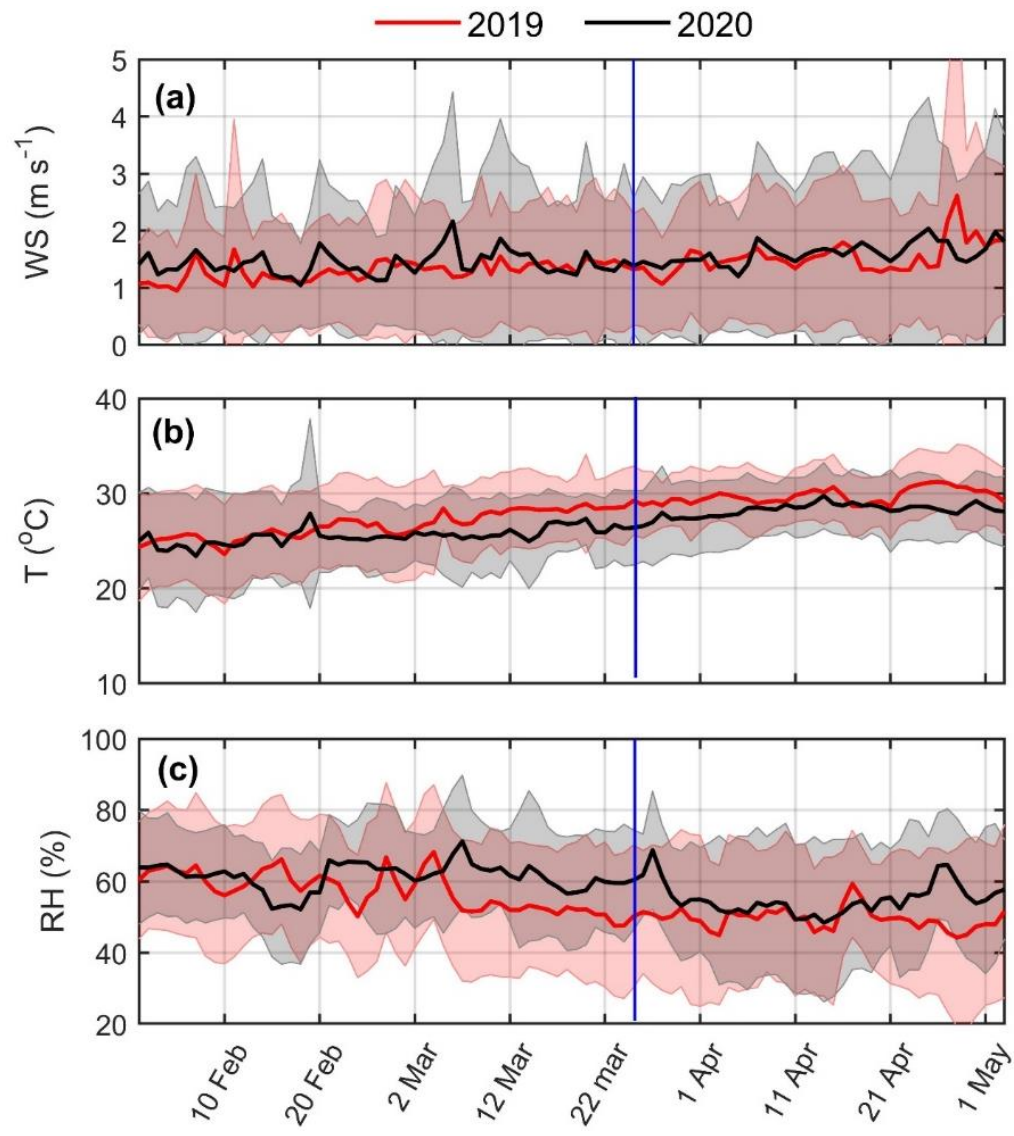

Fig. 2. Daily variation averaged over all the stations for (a) wind speed, (b) temperature, and (c) relative humidity. Shaded areas show standard deviation. The vertical blue line shows the start of the lockdown period in 2020. 
shows, slight reduction during the lockdown over most of the cities as both P20 and L20 are lesser than P19 and P20, respectively, especially in Eastern and Southern India. The relative humidity also shows a good overlap of standard deviation over most of the cities except Chennai and Ahmedabad for the pre-lockdown period, and Delhi, Patna, and Nagpur for the lockdown period. The mean temperature in 2020 is slightly lower than in 2019 for both the time periods (Fig. 2). It can be observed that the diurnal variation of all three meteorological parameters (Fig. S2) show unimodal variation similar to earlier studies (Mahapatra et al., 2013). Wind speed and temperature show a peak at $3 \mathrm{pm}$, meanwhile, $\mathrm{RH}$ shows a trough at the same hour of the day. All three parameters in the diurnal plots show good overlap without any abnormal changes among the four-time periods. Thus, the changes in meteorology are negligible to induce large reductions in the air pollution levels and the decline in pollution levels can likely be attributed to reduced anthropogenic activities during the lockdown (Schiermeier, 2020).

To account for the potential meteorological impact, we examined the percent difference in 2020 relative to 2019 for mean hourly meteorological parameters averaged over 17 cities, as shown in Fig. 3. The relative changes in all parameters during pre-lockdown and lockdown can be seen similar, particularly for temperature. The fluctuation in wind speed and $\mathrm{RH}$ is $\pm 50 \%$, whereas, temperature varies only $\pm 20 \%$ in both these periods over India. During the lockdown period, the relative windspeed is randomly distributed while the temperature and $\mathrm{RH}$ show an overall negative and positive deviation, respectively, from 2019.

Considering low wind speed and temperature with high $\mathrm{RH}$ are favourable to stagnation which lead to higher local pollution levels, and that we have found that RH increased, and temperature and wind speed decreased over most of the cities compared to year 2019, we may have expected higher pollutant concentrations during the lockdown (during L20 vs. L19). Examining the data over five metropolitan cities during the first three weeks of lockdown in India, Jain and Sharma, (2020) suggested that increased WS, and T compared to pre-lockdown period with RH ranging 50-64\% are favourable for lower concentration. However, extent of the changes is similar if compared to analogous period in previous year. Moreover, we find that these meteorological differences in pre-lockdown and lockdown periods were not uniform across the country, the Northern cities experienced higher temperature and low humidity during lockdown while it was other way around in the Southern cities (see Table S2). Hence, these changes in meteorology alone might not be responsible for such large pollution decline across India.

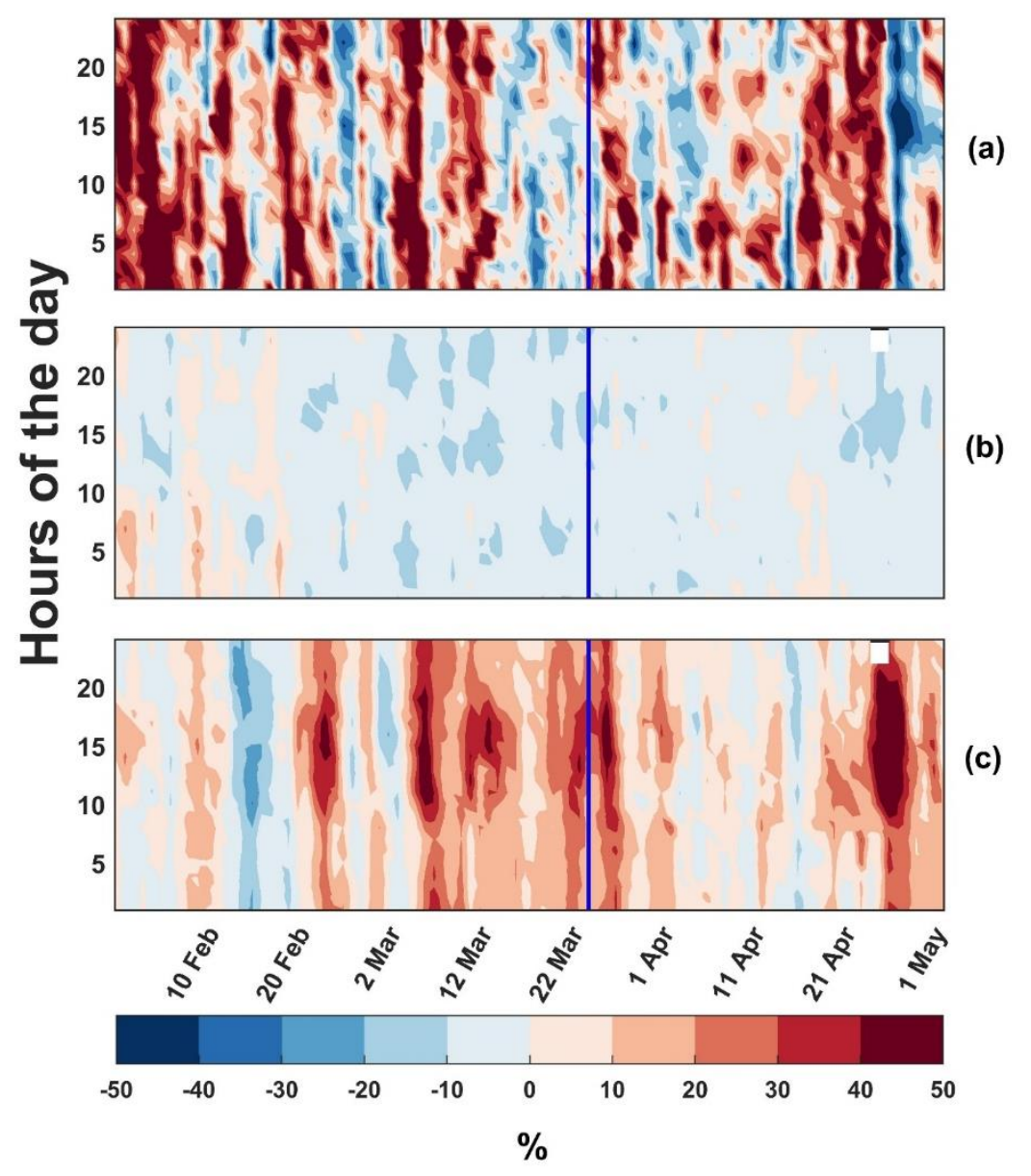

Fig. 3. The percent change in (a) wind speed, (b) temperature and, (c) relative humidity for different days vs. hours in 2020 (compared to previous year, 2019). The vertical blue line shows the start of the lockdown period in 2020. 


\section{Air Quality}

Fig. 4 presents the city-wise mean $( \pm \mathrm{SD})$ of various criteria air pollutants during the four time periods, including the lockdown period (L20). As can be noted, the mean air pollutants concentrations show large heterogeneity over the Indian region with more pollution levels in the Northern cities than the South. The concentration of PMs can be seen higher over the Indo-Gangetic Plain (Delhi, Lucknow, and Patna) which matches the latest study using the same data (Navinya et al., 2020). The standard deviations for P19 vs. P20 periods overlap well with each another for cities except Patna but L19 vs. L20 show the concentrations have reduced significantly over most of the stations for L20 compare to the same period in the previous year. Among all pollutants, $\mathrm{PM}_{2.5}$ and $\mathrm{PM}_{10}$ exhibit the most reduction, in particular, over Delhi, Lucknow, and Ahmedabad during the lockdown. Considering all pollutants, Delhi experienced the highest reduction which varies from $30 \%$ for $\mathrm{CO}$ to $80 \%$ for $\mathrm{NO}_{2}$, and may be attributed to reduced traffic density as a study shows $\sim 72 \%$ of the pollution over Delhi is attributed to the transport sector (Goyal et al., 2006). The reduction over Northern India is much higher than Central China for all the pollutants during a lockdown, especially, Delhi is showing two-fold higher reductions ( $\sim 58 \%$ and $\sim 71 \%$ ) in $\mathrm{PM}_{2.5}$ and
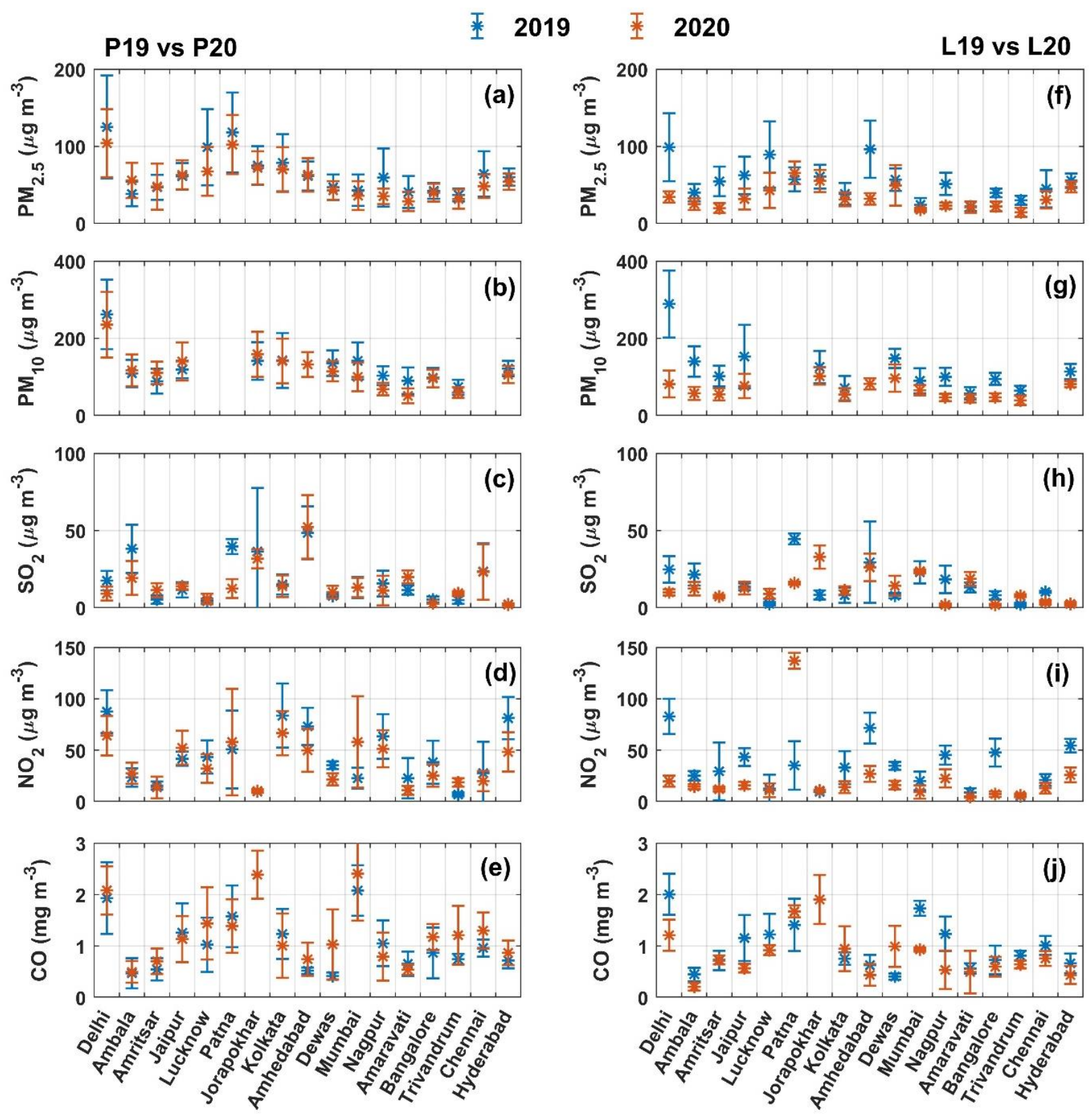

Fig. 4. Station to station variation in pollutants concentration during the four time periods. Here (a), (b), (c), (d), and (e) show the mean station values for P19 vs. P20 periods, while (f), (g), (h), (i), and (j) correspond to L19 vs. L20 for PM 2.5, PM$_{10}$, $\mathrm{SO}_{2}, \mathrm{NO}_{2}$, and $\mathrm{CO}$ respectively. Error bars show the standard deviation. $\mathrm{PM}_{10}$ data is missing for station 5, 6, and 16 for both the years. 2019 data is missing for, $\mathrm{PM}_{10}$ at station $9, \mathrm{SO}_{2}$ at station 3 , and $\mathrm{CO}$ at station 7 . 
$\mathrm{PM}_{10}$ compared to Central China ( $30 \%$ and $41 \%$ ) (Xu et al., 2020) which matches with the reported $\sim 50 \%$ improvement in the AQI of the Delhi during first three weeks of the lockdown (Sharma et al., 2020).

The daily variation in mean air pollution levels across all 17 stations during 14 weeks (comprising of all four time periods) is shown in Fig. 5. It can be seen that $\mathrm{PM}_{2.5}, \mathrm{PM}_{10}$, $\mathrm{NO}_{2}$, and $\mathrm{CO}$ show similar and random variation during the pre-lockdown period for both years (P19 and P20) with well overlapped standard deviations. However, there is a significant decrease in all pollutants except $\mathrm{SO}_{2}$ during the lockdown period (i.e., L20), compared to similar period in 2019, (L19) ( $\mathrm{p}<0.05)$. Also, the sudden decline in mean air pollutant concentrations can be noticed from $22^{\text {nd }}$ March prior to the start of national lockdown, i.e., $25^{\text {th }}$ March. It is because honourable prime minister of India appealed for a voluntary lockdown on 22 Mar, 2020, following which some States started partial lockdown, including stopping within country travel from $23^{\text {rd }}$ March onward. Thus, a large decline of $\sim 40 \%$ can be seen in the immediate few days after the start of the lockdown (Mahato et al., 2020). The diurnal variation of pollutants (see Fig. S3) also does not show appreciable differences in mean $\mathrm{PM}_{2.5}, \mathrm{PM}_{10}$ and $\mathrm{NO}_{2}$ levels between the P19 and L19 periods, however, significant decrease can be seen for these pollutants during lockdown (L20) compared to P20 period for all hours, with a bimodal distribution having peaks in morning (7-10 am) and evening $(7-10 \mathrm{pm})$. $\mathrm{CO}$ also exhibits appreciable reduction during evening hours.

Relative reduction in pollutants levels averaged over all 17 cities by each hour during the lockdown and prelockdown periods is presented in Fig. 6. For all pollutants but $\mathrm{SO}_{2}$ the $\sim 50 \%$ reduction during lockdown (till $3^{\text {rd }}$ May,
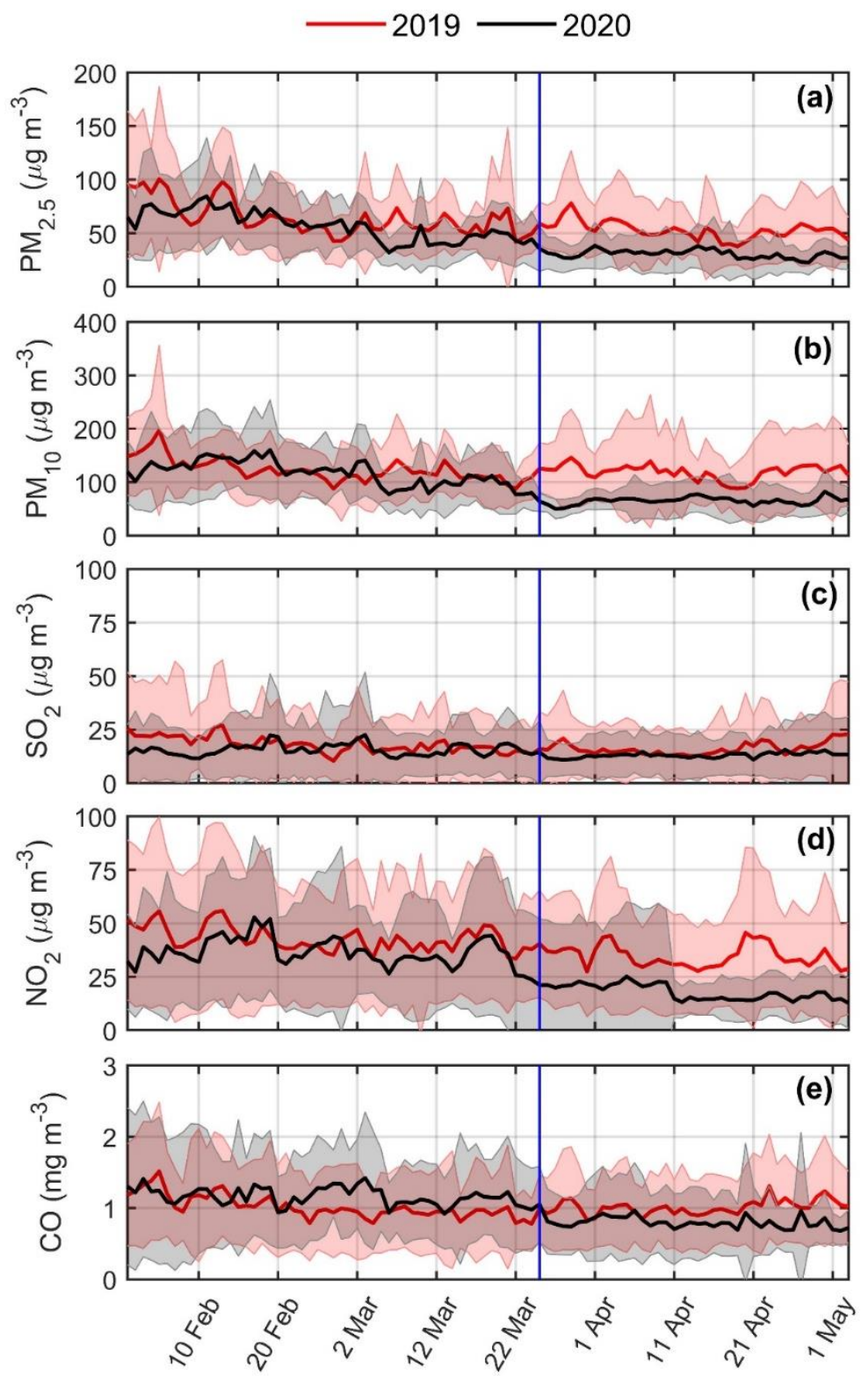

Fig. 5. Daily and diurnal variation averaged over all the stations for (a) $\mathrm{PM}_{2.5}$, (b) $\mathrm{PM}_{10}$, and (c) $\mathrm{SO}_{2}$, (d) $\mathrm{NO}_{2}$, and (e) $\mathrm{CO}$. Shaded areas shows standard. The vertical blue line shows the start of the lockdown period in 2020. 
2020) can be observed, which is much higher than the reduction reported till $14^{\text {th }}$ April, 2020 (Sharma et al., 2020). The highest reduction can be seen during the morning (7$10 \mathrm{am})$ and evening (7-10 pm) periods, likely due to the reduction in traffic emissions, in particular - during these most active periods. Indian traffic pattern is well correlated with pollution concentration in a bimodal variation (Bathmanabhan and Saragur Madanayak, 2010; Goyal et al., 2013). CO shows a larger change in the night time only. In comparison, the pre-lockdown period (P20) shows a large increase in pollutant concentration $>80 \%$ (compared to previous year, P19), especially for CO.

To quantify the impact of lockdown over individual cities across India, we examined the mean percent change in pollutants concentration, as shown in Table 1 . The percent change is normalized to previous year levels (i.e., normalized $\%$ change $=($ L20 - L19 $) /$ L19 $\times 100)$. It can be seen that $\mathrm{PM}_{2.5}$ and $\mathrm{PM}_{10}$ have declined over all the stations with large reduction observed in the Northern region. The mean reduction in cities across India for $\mathrm{PM}_{2.5}, \mathrm{PM}_{10}, \mathrm{NO}_{2}$ and $\mathrm{CO}$ are $35 \%, 40.5 \%, 27.9 \%$ and $13.9 \%$, respectively. $\mathrm{PM}_{2.5}, \mathrm{PM}_{10}, \mathrm{SO}_{2}, \mathrm{NO}_{2}$, and $\mathrm{CO}$ concentrations showed the highest reduction in Ahmedabad (-67.5\%), Delhi (-70.5\%), Nagpur $(-90.6 \%)$, Bangalore (-86.7\%), and Nagpur $(-63.0 \%)$, respectively during the lockdown, which is higher than any reported decline during lockdowns over any other cities (Chauhan and Singh, 2020; Kerimray et al., 2020; Shrestha et al., 2020; Tobías et al., 2020; Venter et al., 2020; Wang et al., 2020; Xu et al., 2020). Similarly, the number of cities with more than $30 \%$ decline (during lockdown compared to pre-lockdown) has increased in 2020 compared to the same period in 2019 (see Table S3). During the lockdown period (25 Mar-3 May), we find 15 (17), 11 (13), 4 (17), 14 (17), and 10 (17) cities in 2020 with more than 30\% decline in $\mathrm{PM}_{2.5}, \mathrm{PM}_{10}, \mathrm{SO}_{2}, \mathrm{NO}_{2}$, and $\mathrm{CO}$ respectively, whereas during the same period in 2019, only 5 (out of 17), 2 (13), 5 (16), 5 (17), and 1 (16) cities experienced a pollution reduction of that magnitude compared to the pre-lockdown period (1 Feb24 Mar). Similarly, more than $30 \%$ decline has been observed during the national lockdown (compared to the same period in 2019) over 10 (out of 17), 10 (13), 13 (17), and 7 (17) cities across India for $\mathrm{PM}_{2.5}, \mathrm{PM}_{10}, \mathrm{NO}_{2}$, and $\mathrm{CO}$, respectively.

The large air quality improvement can be seen in $\mathrm{NO}_{2}$ which also matches with previous studies over China, Almaty and Barcelona (Kerimray et al., 2020; Tobías et al., 2020; Xu et al., 2020). The decline in $\mathrm{NO}_{2}$ reported by Venter et al. (2020) for China and Europe is $12 \%$ and $20 \%$ but 13 out of 17 Indian cities are showing more than $30 \%$ decline in $\mathrm{NO}_{2}$ concentration with highest $87 \%$ change over Bangalore (Venter et al., 2020). The decline in $\mathrm{PM}_{10}$ over

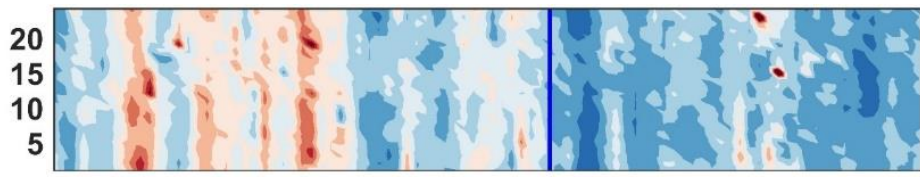

(a)

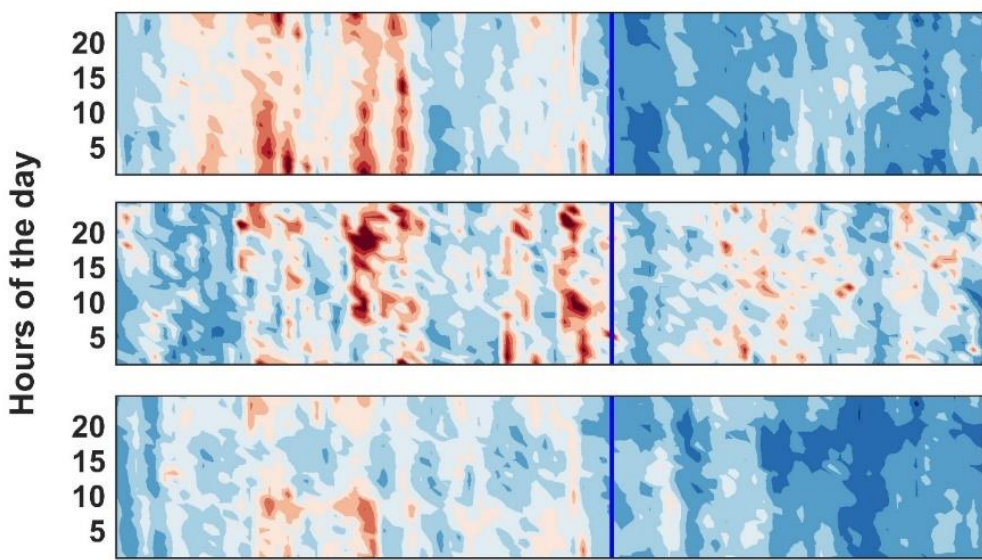

(b)

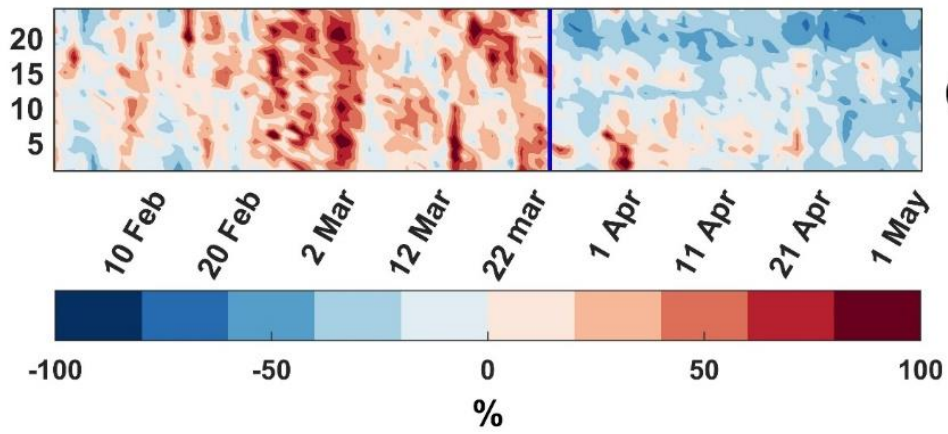

\section{(c)}

(d)

(e)

Fig. 6. The percent change in (a) $\mathrm{PM}_{2.5}$, (b) $\mathrm{PM}_{10}$, (c) $\mathrm{SO}_{2}$, (d) $\mathrm{NO}_{2}$, and (e) CO for days vs. hours variation in 2020. (Compared to previous year, 2019). The vertical blue line shows the start of the lockdown period in 2020. 
Table 1. Percentage change in mean pollutant levels and meteorological parameters during lockdown (L20) with respect to L19. The \% change is normalized to L19 levels i.e., (L20 - L19)/L19 × 100. Bold number indicates p-value < 0.0125. ND = No data.

\begin{tabular}{|c|c|c|c|c|c|c|c|c|c|}
\hline \multirow{2}{*}{ Region } & \multirow{2}{*}{ City } & \multicolumn{8}{|c|}{$\%$ change during COVID-19 lockdown } \\
\hline & & $\mathrm{PM}_{2.5}$ & $\mathrm{PM}_{10}$ & $\mathrm{SO}_{2}$ & $\mathrm{NO}_{2}$ & $\mathrm{CO}$ & WS & $\mathrm{T}$ & RH \\
\hline \multirow[t]{5}{*}{ North } & Delhi & $-\mathbf{5 8 . 1}$ & $-\mathbf{7 0 . 5}$ & -53.2 & -79.2 & -30.2 & 9.3 & ND & 59.4 \\
\hline & Ambala & -37.1 & -60.3 & -36.4 & -42.0 & -39.1 & -1.0 & ND & 14.8 \\
\hline & Amritsar & -64.5 & -41.5 & -86.5 & -38.8 & -5.3 & -14.8 & -8.4 & 24.7 \\
\hline & Jaipur & $-\mathbf{5 0 . 5}$ & -48.1 & -8.9 & -68.4 & $-\mathbf{5 5 . 0}$ & -26.7 & ND & 67.7 \\
\hline & Lucknow & -51.5 & ND & 167.4 & 8.1 & -30.1 & 5.6 & ND & 11.8 \\
\hline \multirow[t]{3}{*}{ East } & Patna & 14.2 & ND & -64.4 & 226.5 & 27.2 & -68.3 & ND & 39.3 \\
\hline & Jorapokhar & -24.7 & -10.2 & 294.3 & 19.1 & ND & ND & -12.6 & -7.2 \\
\hline & Kolkata & -23.5 & -24.2 & 45.6 & -55.9 & 14.8 & -28.4 & -0.8 & -4.1 \\
\hline \multirow[t]{4}{*}{ West } & Ahmedabad & -67.7 & ND & -33.4 & -67.5 & -36.5 & 111.7 & ND & 11.2 \\
\hline & Dewas & -12.9 & -33.1 & 88.4 & -52.4 & 141.0 & 8.7 & 6.5 & 36.0 \\
\hline & Mumbai & -0.9 & -27.3 & 46.9 & $-\mathbf{5 7 . 9}$ & -45.6 & -21.1 & 2.4 & 4.9 \\
\hline & Nagpur & -52.6 & -52.6 & -90.6 & -49.9 & -63.0 & -39.6 & -8.1 & 50.9 \\
\hline \multirow{5}{*}{ South } & Amaravati & -17.7 & -37.9 & 19.4 & -63.9 & -3.6 & -10.5 & 0.1 & 3.8 \\
\hline & Bangalore & -45.4 & -48.9 & -80.5 & -86.7 & -24.2 & -13.4 & -14.1 & 10.8 \\
\hline & Trivandrum & -52.9 & -38.5 & 252.3 & 5.9 & -23.7 & -15.7 & -6.2 & 2.1 \\
\hline & Chennai & -30.2 & ND & -69.2 & -36.3 & -23.7 & -7.1 & ND & -7.2 \\
\hline & Hyderabad & -19.4 & -31.9 & 26.0 & -35.0 & -26.1 & -19.8 & -3.2 & 9.0 \\
\hline
\end{tabular}

Delhi has reported as 32.5\% during March 2020 (Shrestha et al., 2020) but the extension of lockdown, evaluated here, reduced it further to $70 \%$.

A few studies examining the early lockdown effect (of 3 weeks duration), focusing mainly on Delhi show that the pollution level for $\mathrm{PM}_{2.5}, \mathrm{PM}_{10}, \mathrm{NO}_{2}$, and $\mathrm{CO}$ has decreased by $41 \%, 52 \%, 51 \%$ and $28 \%$, respectively till 6 April, 2020 compared to 10 days of pre-lockdown (Jain and Sharma, 2020). Similarly, Sharma et al. (2020) report 43\%, 31\%, $18 \%$, and $10 \%$ decline in these pollutants till 19 April, 2020, respectively. However, both studies tried to link it with the meteorology for Delhi only. Sharma et al. (2020) used WRF AERMOD for predicting $\mathrm{PM}_{2.5}$ under actual and unfavorable meteorological conditions, and predicted higher $\mathrm{PM}_{2.5}$ concentrations during lockdown compared to the observed concentrations, implying the significant impact of activity restrictions during lockdown on improvement in air quality in Delhi. However, Jain and Sharma (2020) has done qualitative comparison over Delhi, showing slight increase in temperature and wind speed which is more favourable to have low concentration as it leads to more dispersion (Jain and Sharma, 2020).

In studies elsewhere, Li et al. (2020) found that the $\mathrm{PM}_{2.5}$ reduced by 27 to $47 \%$ during lockdown I to II over Yangtze River Delta (YRD) region China with no obvious change in meteorology compared to previous year (Li et al., 2020). Kota Damansara region, Malaysia recorded 49\% drop in CO concentration which is highest among all reported studies during lockdown but surprisingly, $\mathrm{PM}_{2.5}$ and $\mathrm{PM}_{10}$ is increased by 60 and $9.7 \%$, respectively which is attributed to increase in local burning (Mohd Nadzir et al., 2020). Chauhan and Singh (2020) reported 11\% reduction in $\mathrm{PM}_{2.5}$ over Dubai during March 2020 compared with 2019, whereas, $\mathrm{PM}_{2.5}$ during March 2020 was reported $24 \%$ and $58 \%$ lesser compared to February 2020 over Rome, Italy and Zaragoza, Spain respectively.

The fraction of days below the NAAQS limits during the two time periods (L19 and L20) is examined, which shows metropolitan areas such as Delhi, Jaipur, Lucknow, Ahmedabad, Nagpur, and Chennai experience > 20\% improvement in $\mathrm{PM}_{2.5}$, whereas, smaller cities such as Dewas and Jorapokhar show lesser improvement (see Table 2). The larger improvement can be observed in the Northern region compared to Central China (Xu et al., 2020) as $70 \%$ extra days are under the NAAQS limit for $\mathrm{PM}_{2.5}$ and $\mathrm{PM}_{10}$ over Delhi during lockdown compared to previous year. $\mathrm{SO}_{2}$ is below the NAAQS for both the time periods as also reported for early lockdown period by Sharma et al. (2020). On the other hand, during lockdown, $100 \%$ days were under the NAAQS limit for $\mathrm{NO}_{2}$ and $\mathrm{CO}$ over all the cities. The two major cities Mumbai and Delhi with highly dense population and $\sim 20 \%$ of the $\mathrm{PM}_{10}$ emissions are from the vehicular sector, shows different changes in pollution level which may be likely attributed to the transport sector as people in Mumbai primarily commute through suburban trains and public transport, whereas, in Delhi relatively more private vehicles are used, resulting in overall $60 \%$ higher energy consumption than Mumbai (Das and Parikh, 2004; Gupta et al., 2012; Sharma et al., 2014). The 4 major cities of Southern India show constant $20 \%$ decline in the $\mathrm{CO}$ concentration but the recent study examining the impact of first three weeks of the national lockdown impact in India (until $14^{\text {th }}$ April, 2020) reported increase in CO compared to the previous year (Sharma et al., 2020).

The observed large decline in most air pollutants over India is much higher than any other reported study during COVID-19 lockdown and cannot be explained by meteorology alone as the changes in meteorological parameters in 2020 (L20-P20) are similar (Table S2) with previous year but the pollutant concentrations differ widely (Table S3). Hence, to 
Table 2. City-wise percentage of days within the NAAQS limits during the lockdown period (L20) compared to corresponding previous year period (L19). ND = No data.

\begin{tabular}{|c|c|c|c|c|c|c|c|c|c|c|c|}
\hline \multirow{2}{*}{ Region } & \multirow{2}{*}{ City } & \multicolumn{2}{|c|}{$\mathrm{PM}_{2.5}$} & \multicolumn{2}{|c|}{$\mathrm{PM}_{10}$} & \multicolumn{2}{|c|}{$\mathrm{SO}_{2}$} & \multicolumn{2}{|c|}{$\mathrm{NO}_{2}$} & \multicolumn{2}{|c|}{$\mathrm{CO}$} \\
\hline & & L19 & L20 & L19 & L20 & L19 & L20 & L19 & L20 & L19 & L20 \\
\hline \multirow[t]{5}{*}{ North } & Delhi & 18 & 86 & 0 & 68 & 100 & 100 & 38 & 100 & 93 & 96 \\
\hline & Ambala & 90 & 100 & 15 & 100 & 100 & 100 & 100 & 100 & 100 & 100 \\
\hline & Amritsar & 65 & 100 & 48 & 91 & 100 & 100 & 95 & 100 & 99 & 100 \\
\hline & Jaipur & 38 & 98 & 10 & 85 & 100 & 100 & 98 & 100 & 96 & 100 \\
\hline & Lucknow & 23 & 83 & ND & ND & 100 & 100 & 100 & 100 & 98 & 100 \\
\hline \multirow[t]{3}{*}{ East } & Patna & 60 & 36 & ND & ND & 100 & 100 & 90 & 0 & 96 & 100 \\
\hline & Jorapokhar & 64 & 80 & 40 & 53 & 100 & 100 & 100 & 100 & ND & 98 \\
\hline & Kolkata & 93 & 100 & 88 & 100 & 100 & 100 & 98 & 100 & 100 & 100 \\
\hline \multirow[t]{4}{*}{ West } & Ahmedabad & 0 & 100 & ND & 95 & 84 & 100 & 68 & 100 & 100 & 100 \\
\hline & Dewas & 70 & 73 & 10 & 53 & 100 & 100 & 100 & 100 & 100 & 100 \\
\hline & Mumbai & 100 & 100 & 78 & 98 & 100 & 100 & 100 & 100 & 100 & 100 \\
\hline & Nagpur & 80 & 100 & 50 & 100 & 100 & 100 & 100 & 100 & 95 & 100 \\
\hline \multirow[t]{5}{*}{ South } & Amaravati & 100 & 100 & 93 & 100 & 100 & 100 & 100 & 100 & 99 & 96 \\
\hline & Bangalore & 100 & 100 & 60 & 100 & 100 & 100 & 98 & 100 & 100 & 100 \\
\hline & Trivandrum & 100 & 100 & 98 & 100 & 100 & 100 & 100 & 100 & 100 & 100 \\
\hline & Chennai & 80 & 100 & ND & ND & 100 & 100 & 100 & 100 & 100 & 100 \\
\hline & Hyderabad & 72 & 97 & 22 & 100 & 100 & 100 & 100 & 100 & 100 & 100 \\
\hline
\end{tabular}

further understand the impact of lockdown only, DiD method was used, where the relative difference in pollutants and meteorological variables in 2020 and 2019 was examined during the lockdown and pre-lockdown periods. The statistical results of this analysis are presented in Table S4. We can note that all pollutants except $\mathrm{SO}_{2}$ are significantly lower during the lockdown $(\mathrm{P}<<<0.05)$, while there is no evidence of statistically significant difference in meteorological parameters $(\mathrm{p}>>0.05)$. The changes in the $\mathrm{SO}_{2}$ during lockdown (until 3 May, 2020) are not significant which is also reported by recent studies examining the early impact of COVID-19 lockdown in India (Jain and Sharma, 2020; Sharma et al., 2020). The cities like Delhi experienced 43, 31,18 , and $10 \%$ reduction in $\mathrm{PM}_{2.5}, \mathrm{PM}_{10}, \mathrm{NO}_{2}$, and $\mathrm{CO}$, respectively, till 19 Apr, 2020 but further dropped to 58, 70, 80 , and $30 \%$ by 3 May, 2020 compared to previous year, respectively (Sharma et al., 2020). Similar drop is seen in the other mega cities - Chennai, Bangalore, and Kolkata as well (Jain and Sharma, 2020). The large decline in air pollutants observed during $\sim 6$ weeks national lockdown in India with smaller changes in meteorology thus suggest that the reduced activities, transportation, in particular, are responsible for the significant improvement in air quality. Considering dynamic nature of meteorology, we also suggest that comparative analysis of natural intervention such as during COVID-19 lockdown should incorporate long term meteorology (of several weeks) when examining the impact of the intervention on air quality.

\section{CONCLUSIONS}

1. The effect of restricted human activities during 6-week long COVID-19 national lockdown on air quality of 17 cities across India is examined. By considering four different timeframes, attempt is made to disentangle the effect of meteorology and the lockdown. A significant decline is observed during lockdown for $\mathrm{PM}_{2.5}, \mathrm{PM}_{10}$, $\mathrm{NO}_{2}$, and $\mathrm{CO}$ with little changes in meteorology compared to the pre-lockdown periods suggesting the reduction in pollution is due to reduced anthropogenic activities during the lockdown.

2. The Largest decline in $\mathrm{PM}_{2.5}, \mathrm{PM}_{10}, \mathrm{NO}_{2}$, and $\mathrm{CO}$ was observed in metropolitan cities Ahmedabad (67\%), Delhi (70\%), Bangalore (86\%), and Nagpur (63\%), respectively.

3. More than $30 \%$ decline has been observed during the national lockdown (compared to same period in the previous year) over 10 (out of 17), 10 (13), 13 (17), and 7 (17) cities across India for $\mathrm{PM}_{2.5}, \mathrm{PM}_{10}, \mathrm{NO}_{2}$, and $\mathrm{CO}$, respectively.

4. All station mean shows, higher reduction (> 40\%) during 7-10 am for $\mathrm{PM}_{2.5}$ and $\mathrm{PM}_{10}$ and during 7-10 pm for $\mathrm{PM}_{2.5}, \mathrm{PM}_{10}, \mathrm{NO}_{2}$, and $\mathrm{CO}$ than other times.

5. Northern region shows the highest decline for all the pollutants with most days $(70-100 \%)$ below NAAQS during lockdown compared to $0-40 \%$ in 2019 for $\mathrm{PM}_{2.5}$, $\mathrm{PM}_{10}$, and $\mathrm{NO}_{2}$.

6. The changes in meteorology during the lockdown are heterogeneous and very small across all the cities, but the large decline is observed in air pollutants which cannot be induced by such small meteorological fluctuations only.

\section{ACKNOWLEDGMENTS}

The authors wish to thank the Central Pollution Control Board $(\mathrm{CPCB} \mid)$ for open access to the air pollution and meteorological data.

\section{DISCLAIMER}

Reference to any company or specific commercial 
products does not constitute financial and personal conflicts of interest.

\section{SUPPLEMENTARY MATERIAL}

Supplementary data associated with this article can be found in the online version at https://aaqr.org/

\section{REFERENCES}

Bao, R. and Zhang, A. (2020). Does lockdown reduce air pollution? Evidence from 44 cities in northern China. Sci. Total Environ. 731: 139052. https://doi.org/10.1016/j.sc itotenv.2020.139052

Bathmanabhan, S. and Saragur Madanayak, S.N. (2010). Analysis and interpretation of particulate matter - $\mathrm{PM}_{10}$, $\mathrm{PM}_{2.5}$ and $\mathrm{PM}_{1}$ emissions from the heterogeneous traffic near an urban roadway. Atmos. Pollut. Res. 1: 184-194. https://doi.org/10.5094/APR.2010.024

Boucher, O., Myhre, G. and Myhre, A. (2004). Direct human influence of irrigation on atmospheric water vapour and climate. Clim. Dyn. 22: 597-603. https://doi. org/10.1007/s00382-004-0402-4

Central Pollution Control Board (CPCB) (2011). Guidelines for the measurement of ambient air pollutants, Volume-I. Central Pollution Control Board Guidelines for Ministry of Environment \& Forests, India.

Central Pollution Control Board (CPCB) (2020). CPCB, Air quality data portal. https://app.cpcbccr.com/ccr/\#/caaqmdashboard-all/caaqm-landing/data

Chaloulakou, A., Kassomenos, P., Spyrellis, N., Demokritou, P. and Koutrakis, P. (2003). Measurements of $\mathrm{PM}_{10}$ and $\mathrm{PM}_{2.5}$ particle concentrations in Athens, Greece. Atmos. Environ. 37: 649-660. https://doi.org/10.1016/S13522310(02)00898-1

Chauhan, A. and Singh, R.P. (2020). Decline in $\mathrm{PM}_{2.5}$ concentrations over major cities around the world associated with COVID-19. Environ. Res. 187: 109634. https://doi.org/10.1016/j.envres.2020.109634

Chen, Q.X., Huang, C.L., Yuan, Y. and Tan, H.P. (2020). Influence of COVID-19 event on air quality and their association in Mainland China. Aerosol Air Qual. Res. https://doi.org/10.4209/aaqr.2020.05.0024

Cleophas, T.J., Zwinderman, A.H., Cleophas, T.J. and Zwinderman, A.H. (2011). Bonferroni t-test. In Statistical analysis of clinical data on a pocket calculator, Springer Netherlands, pp. 41-42. https://doi.org/10.1007/978-94007-1211-9_15

Dantas, G., Siciliano, B., França, B.B., da Silva, C.M. and Arbilla, G. (2020). The impact of COVID-19 partial lockdown on the air quality of the city of Rio De Janeiro, Brazil. Sci. Total Environ. 729: 139085. https://doi.org/1 0.1016/j.scitotenv.2020.139085

Das, A. and Parikh, J. (2004). Transport scenarios in two metropolitan cities in India: Delhi and Mumbai. Energy Convers. Manage. 45: 2603-2625. https://doi.org/10.101 6/j.enconman.2003.08.019

Dutheil, F., Baker, J.S. and Navel, V. (2020). COVID-19 as a factor influencing air pollution? Environ. Pollut. 263:
114466. https://doi.org/10.1016/j.envpol.2020.114466

Environmental Information System (ENVIS) (2020). National Air Quality Monitoring Programme (NAMP), Monitoring Network. CPCB, India. http://cpcbenvis.nic. in/airpollution/monetoring.htm

Filonchyk, M., Hurynovich, V., Yan, H., Gusev, A. and Shpilevskaya, N. (2020). Impact assessment of COVID19 on variations of $\mathrm{SO}_{2}, \mathrm{NO}_{2}, \mathrm{CO}$ and $\mathrm{AOD}$ over East China. Aerosol Air Qual. Res. 20: 1530-1540. https://doi. org/10.4209/aaqr.2020.05.0226

Gautam, S. (2020). The influence of COVID-19 on air quality in India: A boon or inutile. Bull. Environ. Contam. Toxicol. 104: 724-726. https://doi.org/10.1007/s00128020-02877-y

Ghei, D. and Sane, R. (2018). Estimates of air pollution in Delhi from the burning of firecrackers during the festival of Diwali. PLoS One 13: 1-11. https://doi.org/10.1371/jo urnal.pone.0200371

Goyal, P., Mishra, D. and Kumar, A. (2013). Vehicular emission inventory of criteria pollutants in Delhi. Springerplus 2: 216. https://doi.org/10.1186/2193-1801-2216

Goyal, S.K., Ghatge, S.V., Nema, P. and Tamhane, S.M. (2006). Understanding urban vehicular pollution problem vis-a-vis ambient air quality--case study of a megacity (Delhi, India). Environ. Monit. Assess. 119: 557-569. https://doi.org/10.1007/s10661-005-9043-2

Gupta, I., Salunkhe, A., Kumar, R. and Stedman, D.H. (2012). Source apportionment of $\mathrm{PM}_{10}$ by positive matrix factorization in urban area of Mumbai, India. Sci. World J. 2012: 13. https://doi.org/10.1100/2012/585791

He, G., Pan, Y. and Tanaka, T. (2020). COVID-19, city lockdown, and air pollution: Evidence from China. medRxiv 2020.03.29.20046649 https://doi.org/10.1101/2 020.03.29.20046649

Huang, C., Wang, Y., Li, X., Ren, L., Zhao, J., Hu, Y., Zhang, L., Fan, G., Xu, J., Gu, X., Cheng, Z., Yu, T., Xia, J., Wei, Y., Wu, W., Xie, X., Yin, W., Li, H., Liu, M., ... Cao, B, (2020). Clinical features of patients infected with 2019 novel coronavirus in Wuhan, China. Lancet 395: 497-506. https://doi.org/10.1016/S0140-6736(20)30183-5

India Meteorological Department (IMD) (2020). New normal dates of onset/progress and withdrawal of Southwest Monsoon over India. India.

Isaifan, R.J. (2020). The dramatic impact of Coronavirus outbreak on air quality: Has it saved as much as it has killed so far? Global J. Environ. Sci. Manag. 6: 275-288. https://doi.org/10.22034/gjesm.2020.03.01

Jain, S. and Sharma, T. (2020). Social and travel lockdown impact considering coronavirus disease (COVID-19) on air quality in megacities of India: Present benefits, future challenges and way forward. Aerosol Air Qual. Res. 20: 1222-1236. https://doi.org/10.4209/aaqr.2020.04.0171

Kerimray, A., Baimatova, N., Ibragimova, O.P., Bukenov, B., Kenessov, B., Plotitsyn, P. and Karaca, F. (2020). Assessing air quality changes in large cities during COVID-19 lockdowns: The impacts of traffic-free urban conditions in Almaty, Kazakhstan. Sci. Total Environ. 730: 139179. https://doi.org/10.1016/j.scitotenv.2020.139179 
Kothawale, D., Munot, A. and Krishna Kumar, K. (2010). Surface air temperature variability over India during 1901-2007, and its association with ENSO. Clim. Res. 42: 89-104. https://doi.org/10.3354/cr00857

Lani, J. (2010). ANOVA (Analysis of Variance). Statistics Solution. https://pdfs.semanticscholar.org/c308/ff16126 67893f3c91b2bf27c84eb4a0e5203.pdf

Li, L., Li, Q., Huang, L., Wang, Q., Zhu, A., Xu, J., Liu, Z., Li, H., Shi, L., Li, R., Azari, M., Wang, Y., Zhang, X., Liu, Z., Zhu, Y., Zhang, K., Xue, S., Ooi, M.C.G., Zhang, D. and Chan, A. (2020). Air quality changes during the COVID-19 lockdown over the Yangtze River Delta Region: An insight into the impact of human activity pattern changes on air pollution variation. Sci. Total Environ. 732: 139282. https://doi.org/10.1016/j.scitotenv.2020.139282

Liu, F., Page, A., Strode, S.A., Yoshida, Y., Choi, S., Zheng, B., Lamsal, L.N., Li, C., Krotkov, N.A., Eskes, H., van $\operatorname{der}$ A, R., Veefkind, P., Levelt, P.F., Hauser, O.P. and Joiner, J. (2020). Abrupt decline in tropospheric nitrogen dioxide over China after the outbreak of COVID-19. Sci. $A d v$. eabc2992. https://doi.org/10.1126/sciadv.abc2992

Lu, H. (2020). Drug treatment options for the 2019-new coronavirus (2019-nCoV). Biosci. Trends. 14: 69-71. https://doi.org/10.5582/BST.2020.01020

Lu, H., Stratton, C.W. and Tang, Y.W. (2020). Outbreak of pneumonia of unknown etiology in Wuhan, China: The mystery and the miracle. J. Med. Virol. 92: 401-402. https://doi.org/10.1002/jmv.25678

Mahapatra, P.S., Panda, S., Das, N., Rath, S. and Das, T. (2013). Variation in black carbon mass concentration over an urban site in the eastern coastal plains of the Indian sub-continent. Theor. Appl. Climatol. 117: 133147. https://doi.org/10.1007/s00704-013-0984-z

Mahato, S., Pal, S. and Ghosh, K.G. (2020). Effect of lockdown amid COVID-19 pandemic on air quality of the megacity Delhi, India. Sci. Total Environ. 730: 139086. https://doi.org/10.1016/j.scitotenv.2020.139086

McNeill, V.F. (2020). COVID-19 and the air we breathe. ACS Earth Space Chem. 5: 674-675. https://doi.org/10.1 021/acsearthspacechem.0c00093

Ministry of Home Affairs (MHA) (2020a). Government of India issues orders prescribing lockdown for containment of COVID-19 epidemic in the country. Ministry of Home Affairs, Government of India, India.

Ministry of Home Affairs (MHA) (2020b). Government of India issues orders extension of lockdown (No. 403/2020-DM-I(A). Ministry of Home Affairs, Government of India, India.

Mohd Nadzir, M.S., Ooi, M.C.G., Alhasa, K.M., Bakar, M.A.A., Mohtar, A.A.A., Nor, M.F.F.M., Latif, M.T., Hamid, H.H.A., Ali, S.H.M., Ariff, N.M., Anuar, J., Ahamad, F., Azhari, A., Hanif, N.M., Subhi, M.A., Othman, M. and Nor. M.Z.M. (2020). The impact of movement control order (MCO) during pandemic COVID-19 on local air quality in an urban area of Klang Valley, Malaysia. Aerosol Air Qual. Res. 20: 1237-1248. https://doi.org/10.4209/aaqr.2020.04.0163

MoHFW India (2020). Home page. https://www.mohfw. gov.in/
Myllyvirta, L. (April 30, 2020). 11,000 air pollution-related deaths avoided in Europe as coal, oil consumption plummet. https://energyandcleanair.org/air-pollution-deaths-avoidedin-europe-as-coal-oil-plummet/?fbclid=IwAR0bS0vyQD 3J0WeV6re-CTxtcXcB0jW6P4AYWH9vxNH8ghCq2S HeeMf0lAI

National Aeronautics and Space Administration (NASA) (2020). Airborne nitrogen dioxide plummets over China. https://earthobservatory.nasa.gov/images/146362/airbor ne-nitrogen-dioxide-plummets-over-china

Navinya, C.D., Vinoj, V. and Pandey, S.K. (2020). Evaluation of $\mathrm{PM}_{2.5}$ surface concentrations simulated by NASA's MERRA Version 2 aerosol reanalysis over India and its relation to the air quality index. Aerosol Air Qual. Res. 20: 1329-1339 https://doi.org/10.4209/aaqr.2019.1 2.0615

Pandey, A. and Venkataraman, C. (2014). Estimating emissions from the Indian transport sector with on-road fleet composition and traffic volume. Atmos. Environ. 98: 123-133. https://doi.org/10.1016/j.atmosenv.2014.08.039

Ramachandra, T.V. and Shwetmala. (2009). Emissions from India's transport sector: Statewise synthesis. Atmos. Environ. 43: 5510-5517. https://doi.org/10.1016/j.atmos env.2009.07.015

Schiermeier, Q. (2020). Why pollution is plummeting in some cities - but not others. Nature. 580: 313. https://doi.org/10.1038/d41586-020-01049-6

Sharma, S., Zhang, M., Anshika, Gao, J., Zhang, H. and Kota, S.H. (2020). Effect of restricted emissions during COVID-19 on air quality in India. Sci. Total Environ. 728: 138878. https://doi.org/10.1016/j.scitotenv.2020.138878

Sharma, S.K., Mandal, T.K., Saxena, M., Rashmi, Rohtash, Sharma, A. and Gautam, R. (2014). Source apportionment of $\mathrm{PM}_{10}$ by using positive matrix factorization at an urban site of Delhi, India. Urban Clim. 10: 656-670. https://doi.org/10.1016/j.uclim.2013.11.002

Shrestha, A.M., Shrestha, U.B., Sharma, R., Bhattarai, S., Tran, H.N.T. and Rupakheti, M. (2020). Lockdown caused by COVID-19 pandemic reduces air pollution in cities worldwide. EarthArXiv https://doi.org/10.31223/os f.io/edt4j

Tett, S.F.B., Stott, P.A., Allen, M.R., Ingram, W.J. and Mitchell, J.F.B. (1999). Causes of twentieth-century temperature change near the Earth's surface. Nature 399: 569-572. https://doi.org/10.1038/21164

Tobías, A., Carnerero, C., Reche, C., Massagué, J., Via, M., Minguillón, M.C., Alastuey, A. and Querol, X. (2020). Changes in air quality during the lockdown in Barcelona (Spain) one month into the SARS-CoV-2 epidemic. Sci. Total Environ. 726: 138540. https://doi.org/10.1016/j.sc itotenv.2020.138540

Venter, Z.S., Aunan, K., Chowdhury, S. and Lelieveld, J. (2020). COVID-19 lockdowns cause global air pollution declines with implications for public health risk. medRxiv 2020.04.10.20060673. https://doi.org/10.1101/2020.04.1 0.20060673

Wallace, J. and Kanaroglou, P. (2009). The effect of temperature inversions on ground-level nitrogen dioxide $\left(\mathrm{NO}_{2}\right)$ and fine particulate matter $\left(\mathrm{PM}_{2.5}\right)$ using temperature 
profiles from the Atmospheric Infrared Sounder (AIRS). Sci. Total Environ. 407: 5085-5095. https://doi.org/10.1 016/j.scitotenv.2009.05.050

Wang, P., Chen, K., Zhu, S., Wang, P. and Zhang, H. (2020). Severe air pollution events not avoided by reduced anthropogenic activities during COVID-19 outbreak. Resour. Conserv. Recycl. 158: 104814. https://doi.org/10. 1016/j.resconrec.2020.104814

World Health Organization (WHO) (2020). Coronavirus disease (COVID-19), Situation Report - 109. https://www.who.int/docs/default-source/coronaviruse/si tuation-reports/20200508covid-19-sitrep-109.pdf?sfvrsn $=68 \mathrm{f} 2 \mathrm{c} 632 \_6$

Wu, J., Zha, J., Zhao, D. and Yang, Q. (2018). Changes in terrestrial near-surface wind speed and their possible causes: An overview. Clim. Dyn. 51: 2039-2078 https://doi.org/10.1007/s00382-017-3997-y

Xu, K., Cui, K., Young, L.H., Hsieh, Y.K., Wang, Y.F., Zhang, J. and Wan, S. (2020). Impact of the COVID-19 event on air quality in Wuhan, Jingmen, and Enshi Cities, China. Aerosol Air Qual. Res. 20: 915-929. https://doi.o rg/10.4209/aaqr.2020.04.0150

Received for review, May 23, 2020

Revised, June 18, 2020

Accepted, June 20, 2020 